\title{
MENGGALI MOTIVASI GURU AGAMA KATOLIK DI SEKOLAH TINGGI PASTORAL KATEKETIK (STPK) SANTO BENEDIKTUS SORONG
}

\author{
Ady Bintoro
}

\begin{abstract}
:
A Catholic teacher, while he/she is open to the situation of contemporary world, leads his/her students to promote the good of our earthly city and prepares them for the service of others and therefore to let God's Kingdom come. Guided by an exemplary apostolic life they become as it were a saving leaven in a human community. They should therefore be very carefully prepared so that both in secular and religious knowledge they are equipped with suitable qualifications and also with a pedagogical skill that is in keeping with the findings of the contemporary world. Intimately linked in charity to one another and to their students and endowed with an apostolic spirit, may teachers by their life as much as by their instruction bear witness to Christ. The problem is who will be interested to be a Catholic teacher today? This article aims to support people especially who wants to be a Catholic as well as a teacher.
\end{abstract}

\section{Kata-kata Kunci:}

Pendidikan Katolik, guru, panggilan hidup, pastoral kateketik, relevansi, STPK.

\section{PENGANTAR}

Sebagai sebuah ilustrasi, ada sekitar 50 anak Sekolah Dasar. Kepada mereka ditanyakan: "Siapa yang bercita-cita ingin menjadi seorang guru?" Kira-kira dari 50 anak itu berapa anak yang akan menjawab bercita-cita menjadi seorang guru? Jika kemudian pertanyaan dilanjutkan: "Siapa yang bercita-cita menjadi guru agama?" Kira-kira berapa dari mereka yang akan menjawab? Dari ilustrasi ini, peneliti ingin menunjukkan bahwa pilihan hidup menjadi seorang guru, bisa jadi bukanlah pilihan hidup yang populer lagi pada zaman modern seperti ini, tidak menjadi pilihan hidup yang menarik untuk anak-anak zaman sekarang ini. Lebih spesifik lagi pilihan hidup menjadi guru Agama (Katolik) apakah menjadi pilihan hidup yang menarik?

Seorang guru (dalam bahasa Jawa Guru berarti "digugu": didengarkan perkataannya dan "ditiru": diteladani tindakannya) menjadi sosok yang sangat penting dalam penanaman nilai-nilai pendidikan dan kepribadian. Dalam proses pendidikan, seorang guru mulai membentuk anak didik untuk mempunyai hasrat dan habitus yang 
mengarah pada keutamaan (seperti: keberanian, persahabatan, kemurahan hati, keadilan, keunggulan, dan semacamnya). Dalam Dokumen Konsili Vatikan Konstitusi Gaudium et Spesart. 10 disebutkan bahwa "Tujuan pendidikan dalam arti sesungguhnya ialah mencapai pembinaan pribadi manusia dalam perspektif tujuan akhirnya dan demi kesejahteraan kelompok-kelompok masyarakat, mengingat bahwa manusia termasuk anggotanya, dan bila sudah dewasa ikut berperan menunaikan kewajibannya."Betapa penting dan berartinya pendidikan dalam kehidupan manusia. Tidak dapat kita pungkiri bahwa tujuan pendidikan yang semacam itu bisa tercapai dan tertanam dalam diri anak didik karena juga banyak campur tangan dan peran serta dari seorang guru. Bagaimana dengan guru agama Katolik? Jelas guru agama Katolik mempunyai panggilan hidup yang khas. Mereka tidak hanya mendidik dan mengajar tetapi sekaligus juga menanamkan nilainilai iman Katolik dalam diri anak didik. Mereka tidak hanya membuat anak didik menjadi pintar secara intelektual tetapi juga membentuk anak didik memiliki kualitas iman yang lebih unggul. Apa gunanya orang memiliki pendidikan dan keterampilan yang tinggi tetapi tidak dibarengi dengan kualitas iman yang baik.

\section{PERMASALAHAN: KONSEP DASAR PENDIDIKAN}

Menurut Kamus Besar Bahasa Indonesia (1991), pendidikan sesungguhnya adalah suatu usaha sadar yang dilakukan manusia melalui suatu proses perubahan sikap dan tatalaku seseorang atau kelompok orang dalam usaha mendewasakan manusia dengan upaya pengajaran dan pelatihan. Dalam arti itu, kita bisa katakan bahwa pengertian atau konsep pendidikan memiliki makna yang luas dan mendalam, yang dibedakan dari istilah "pembelajaran" atau "pengajaran". Definisi tersebut menerangkan beberapa variabel konseptual berkaitan dengan "pendidikan", yaitu: 1) faktor kesadaran atau akal sehat, 2) tindakan yang dibuat oleh manusia, 3) adanya proses perubahan, 4) berfokus pada sikap dan perilaku, 5) seseorang atau sekelompok orang, 6) tujuan pendewasaan, 7) metode pengajaran dan pelatihan.

Pendidikan merupakan usaha manusia untuk menghasilkan atau menciptakan suatu perubahan hidup, baik secara internal (sifat, perilaku, pengetahuan, kecerdasan, keahlian) maupun secara eksternal (perubahan pola dan tatanan hidup masyarakat, pengaruh pada perkembangan alam dan lingkungan, perkembangan nilai-nilai budaya, moral dan lain-lain). Pandangan tersebut memberi makna bahwa pendidikan adalah segala situasi hidup yang mempengaruhi pertumbuhan individu sebagai pengalaman belajar yang berlangsung dalam segala lingkungan dan sepanjang hidup. ${ }^{1}$ Dalam arti sempit, pendidikan adalah pengajaran yang diselenggarakan umumnya di sekolah sebagai salah satu lembaga pendidikan formal.

Ilmu pendidikan juga populer disebut sebagai ilmu pedagogik. Ilmu pedagogik dapat dirumuskan dalam 2 pengertian, yaitu: (1) berkaitan dengan praktik atau cara mengajar seseorang, dan (2) ilmu atau pengetahuan tentang prinsip-prinsip dan metode mengajar, membimbing dan mengawasi pelajaran. ${ }^{2}$ Dua pengertian ini hendak merumuskan sebenarnya pengertian hakiki dari konsep dasar "pedagogi" yakni aspek kognitif (penguasaan kompleksitas ilmu mengajar) dan aspek praktis (proses atau kegiatan belajar-mengajar).

Pendidikan dapat dimaknai sebagai suatu proses mengubah tingkah laku "anak didik" agar menjadi manusia dewasa yang mampu hidup mandiri dan sebagai anggota masyarakat dalam lingkungan alam sekitar di mana individu itu berada. Pendidikan tidak hanya mencakup aspek intelektualitas saja, melainkan pula aspek-aspek lain, seperti personalitas, sosialitas, moralitas, kulturalitas, dan sebagainya. ${ }^{3}$

Dari sudut pandang proses, pendidikan adalah usaha mempengaruhi peserta didik secara positif dan berkesinambungan supaya mampu menyesusaikan diri sebaik mungkin dengan lingkungannya sehingga menghasilkan interaksi yang bermanfaat bagi masa depannya dan juga masa depan masyarakat itu sendiri. Ilmu pendidikan sesungguhnya bukan sekedar suatu usaha 
untuk mendewasakan atau mengembangkan kepribadian individu secara personal, melainkan suatu upaya sadar untuk memajukan kualitas hidup masyarakat itu sendiri. ${ }^{4}$ Sedangkan bila dipandang dari sudut definisi, maka pendi-dikan adalah usaha sadar yang dilakukan oleh individu, keluarga, masyarakat dan pe-merintah melalui kegiatan bimbingan, pengajaran, dan atau latihan-latihan, baik yang berlangsung di sekolah (atau kampus) maupun di luar sekolah. Adapun usaha sadar tersebut dilakukan dalam bentuk pembelajaran sesuai metode dan prosedur pendidikan yang diterapkan secara logis, sistematis, koheren, dan efektif serta efisien.

Pemerintah dan masyarakat sebagai salah satu elemen konstitutif pendidikan, juga harus menunjukkan sikap bertanggungjawab dengan memberikan dukungan dan bantuan yang konstruktif. Pemerintah sendiri telah mencantumkan dengan jelas tujuan pendidikan, terutama pendidikan tinggi, sebagaimana tercantum dalam Peraturan Pemerintah (PP) No. 60 tahun 1999, Bab II, pasal 2, ayat 1 tentang Tujuan Pendidikan Tinggi, yang dapat diuraikan sebagai berikut:

1. Tujuan Pendidikan Tinggi adalah:

a. Menyiapkan peserta didik menjadi anggota masyarakat yang memiliki kemampuan akademik dan/atau profesional yang dapat menerapkan, pengembangan dan/atau memperkaya khasana ilmu pengetahuan, teknologi dan/atau kesenian.

b. Mengembangkan dan menyebarluaskan ilmu pengetahuan, teknologi dan/atau kesenian serta mengupayakan penggunaan untuk meningkatkan taraf kehidupan masyarakat dan memperkaya kebudayaan nasional.

2. Penyelenggaraan kegiatan untuk mencapai tujuan sebagaimana dimaksud dalam ayat (1) berpedoman pada:

a. Tujuan pendidikan

b. Kaidah, moral dan etika ilmu pengetahuan

c. Kepentingan masyarakat, serta

d. Memperhatikan minat, kemampuan dan prakarsa pribadi.
Dari point-point tersebut di atas, pada dasarnya tujuan pendidikan tinggi adalah untuk meningkatkan kualitas manusia Indonesia, yaitu: manusia yang beriman dan bertakwa kepada Tuhan Yang Maha Esa, berbudi pekerti luhur, berkepribadian, berdisiplin, bekerja keras, tangguh, bertanggungjawab, mandiri, cerdas, dan terampil serta sehat jasmani dan rohani. Pendidikan nasional juga harus mampu menumbuh dan memperdalam rasa cinta tanah air, mempertebal semangat kebangsaan dan kesetiakawanan sosial.

Sejalan dengan itu, maka setiap dalam keseluruhan kehidupan dalam sebuah Perguruan Tinggi harus dikembangkan iklim belajar mengajar yang dapat menumbuhkan rasa percaya pada diri sendiri, serta sikap dan perilaku yang kreatifdan inovatif. Dengan demikian, pendidikan nasional akan mampu mewujudkan manusia-manusia pemba-ngunan yang dapat membangun dirinya sendiri serta bersama-sama bertanggung-jawab atas pembangunan bangsa.

\section{GAMBARAN UMUM KOTA SORONG ${ }^{5}$}

Nama Sorong, secara etimologis berasal dari bahasa Biak Numfor yang disebut dengan kata "Soren". Suku Biak Numfor sejak dahulu dikenal sebagai salah satu suku di Papua yang memiliki keberanian di tengah lautan dengan melakukan pelayaran-pelayaran dari satu pulau ke pulau lain hanya menggunakan perahuperahu tradisional.

Konon kata "Soren" digunakan oleh para pelayar dari Biak untuk menamai lautan di wilayah Sorong. Soren dalam bahasa Biak Numfor berarti laut yang dalam dan bergelombang. Memang lautan wilayah Sorong dikenal sebagai lautan yang cukup dalam dan memiliki gelombang cukup tinggi. Kata Soren ini yang kemudian dilafalkan oleh para pedagang Tionghoa, Misionaris dari Eropa, Maluku dan Sanger Talaut dengan sebutan Sorong. Akhirnya, sebutan Sorong dikenal hingga saat ini sebagai nama wilayah di "Daratan Maladum".

Pertumbuhan kota Sorong tidak terlepas dari peran perusahaan-perusahaan 
yang awalnya menanamkan modalnya di tanah Papua ini. Berawal dari perusahaan NNGPM (Nederlandsche Nieuw Guinea Petroleum Maatschappij) yang beroperasi di Babo (Kabupaten Teluk Bintuni) sejak tahun 1941. Perusahaan yang hadir di tanah Papua memberikan kontribusi besar dalam menumbuh-kembangkan sebuah wilayah menjadi daerah yang maju. Bukan hanya jumlah tenaga yang memacu meningkatnya jumlah penduduk, tetapi pembangunan infrastruktur pun mulai berkembang. Pembangungan-pembangunan secara fisik mulai digalakkan.

Keadaan topografi kota Sorong sangat bervariasi terdiri dari pegunungan lereng, bukit-bukit dan sebagian adalah dataran rendah, sebelah Timur di kelilingi hutan lebat yang merupakan hutan lindung dan hutan wisata. Kota Sorong merupakan kota yang memiliki potensi perkembangan pembangunan cukup pesat. Sebab, secara geografis letak kota Sorong berada pada posisi paling barat pulau besar Papua. Dengan posisi itu, kota Sorong menjadi pintu gerbangnya provinsi Papua Barat dan provinsi Papua. Pada umumnya, perjalanan-perjalanan ke wilayah Papua lainnya, teristimewa dengan menggunakan angkutan kapal penumpang, selalu menyinggahi dahulu kota Sorong. Selain menjadi pintu gerbang dan kota persinggahan karena letaknya yang sangat strategis, kota Sorong juga merupakan kota industri, perdagangan dan jasa. Perkem-bangan dunia industri, perdagangan serta jasa amat sangat berkembang.

Kota Sorong juga sangat dikenal dengan kota minyak. NNGPM merupakan salah satu perusahaan yang merintis pengeboran minyak di tanah Sorong. Hingga sekarang masih banyak perusahaan-perusahaan yang bekerja untuk mengebor minyak di kota Sorong. Di kota Sorong juga masih berserakan sisa-sisa peninggalan sejarah bekas perusahaan minyak milik Belanda. Peninggalan bersejarah dari perusahaan itu adalah Pelabuhan Eksport Minyak Bumi, beberapa tangki penampungan minyak, rumah tinggal karyawan, bekas barak karyawan, bekas sekolah teknik.
Dari segi keagamaan, Sorong merupakan kota yang sangat majemuk. Walaupun awalnya hanya Protestan dan Islam yang masuk wilayah Sorong, tetapi perkembangan kehidupan keagamaan berjalan cukup pesat. Seiring dengan pertumbuhan keagamaan yang pesat itu, keharmonisan juga mulai menampakkan kerukunan. Umat beragama di kota Sorong cukup memberikan penghargaan satu dengan yang lain. Pertumbuhan pemeluk umat agama yang cukup pesat ini juga sangat mempengaruhi perkembangan pembangunan tempattempat ibadah.

Peran keagamaan sangat menonjol dalam pembangunan masyarakat di kota Sorong. Nampak sangat jelas bahwa lembaga-lembaga keagamaan sangat peduli terhadap upaya mencerdaskan kehidupan bangsa dengan mendirikan sekolah-sekolah. Misalnya, Yayasan Pendidikan dan Persekolahan Katolik Keuskupan ManokwariSorong (YPPK KMS) dan Yayasan Paramitha, merupakan bukti bahwa Gereja Katolik sangat peduli terhadap pendidikan. Bukan hanya di bidang keagamaan, bidang kesehatan juga mendapat perhatian yang serius oleh lembaga keagamaan. Poliklinik Bintang Timur dan Poliklinik Malanu merupakan pelayanan jasa pendidikan. Yayasan St. Agustinus merupakan yayasan Katolik yang bergerak untuk mengentaskan Papua dari virus HIV/AIDS. Semuanya ini merupakan bukti bahwa Gereja Katolik memiliki kepeduliaan terhadap keadaan kesehatan masyarakat di kota Sorong dan sekitarnya.Bila dikaji lebih mendalam dan terperinci masih banyak keunggulankeunggulan Kota Sorong, walau juga menyimpan begitu banyak permasalahanpermasalahan sosial.

\section{SEKOLAH PARA CALON GURU AGAMA KATOLIK DI BUMI PAPUA ${ }^{6}$}

Sekolah Tinggi Pastoral Kateketik (STPK) Santo Benediktus ${ }^{7}$ adalah sebuah sekolah yang memang menjalankan seluruh proses pendidikannya untuk mendidik para calon guru agama Katolik. Sejak awal kiprahnya, STPK St. Benediktus berupaya menyelenggarakan pendidikan dan pembinaan bagi Guru Agama Katolik dan caloncalon Guru Agama Katolik, demi penye- 
baran Kabar Gembira di Tanah Papua ${ }^{8}$ dan demi peningkatan kualitas hidup beriman dan mutu pendidikan di daerah terpencil.

Harus diakui bahwa tingkat pendidikan di tanah Papua, secara khusus di Sorong, masih belum sesuai dengan harapan. Masih begitu banyak daerah yang belum tersentuh dengan kemajuan, perkembangan, di antaranya yang paling memprihatinkan adalah pendidikan. Begitu banyak anakanak Papua di pedalaman yang belum mendapat perhatian dan belum mendapat kesempatan mengenyam pendidikan, entah karena fasilitas yang tidak memadai ataupun tidak tersedianya tenaga pendidik.

Dalam era perubahan multi dimensi yang terjadi dewasa ini, dengan berbagai tantangan pada kenyataannya, STPK Santo Benediktus Soronghadir. Adapun tantangan yang dihadapi dewasa ini dan membutuhkan jawaban nyata adalah kenyataankenyataan bahwa :

a. Semakin meningkatnya jumlah lulusan SMU yang tidak dapat melanjutkan pendidikannya ke luar daerah, pada bidang ilmu yang diminatinya, khususnya pada pendidikan agama, karena alasan ekonomi dan kesempatan.

b. Semakin meningkatkan kesadaran masyarakat akan pentingnya pendidikan, khususnya pendidikan tinggi yang langsung mengarah pada kebutuhan lapangan kerja.

c. Tuntutan era pembangunan akan tenaga-tenaga dalam bidang pendidikan agama Katolikyang ada dalam lingkungan STPK, yang lebih tinggi jenjangnya.

d. Adanya dilema bahwa pendidikan tinggi yang bermutu dan berbobot menimbulkan konsekuensi kebutuhan dana yang lebih besar baik secara vertikal maupun horisontal, berarti kewajiban finansial yang harus dipikul yayasan sebagai lembaga penyelenggara pendidikan dan mahasiswa semakin berat.

Tantangan-tantangan tersebut memerlukan tenaga-tenaga pendidik dan pengajar yang handal, yang diharapkan dapat menghadapi dan mengatasi secara profesional dengan penyelenggara kegiatan akademik dan manajemen yang lebihbaik.Untuk itu, dikembangkanlah usaha-usaha nyata dalam keberadaan STPK Santo Benediktus Sorong, yakni :

a. Melaksanakan Tri Darma Perguruan Tinggi, yakni: pengajaran, penelitian, dan pengabdian masyarakat, serta berupaya untuk berperan sebagai agen perubahan dalam masyarakat, dalam bidang pastoral;

b. Mendidik para mahasiswa agar menjadi manusia yang berjiwa luhur, berwawasan luas, menguasai dan mampu menerapkan ilmu pastoral dan kateketik agar siap terjun dalam dunia Pendidikan Keagamaan Katolik di Sorong pada khususnya dan Papua pada umumnya, baik sebagai insan intelektual dengan semangat Katolik, maupun sebagai warga negara yang bertanggung jawab kepada dirinya sendiri, daerah, bangsa dan negara dalam arti yang sesungguhnya; Menjadikan STPK sebagai pusat pemeliharaan serta pengembangan ilmu-ilmu pastoral dan keterampilan berpastoral serta mengajar agama Katolik, sesuai dengan kebutuhan masyarakat agama pada umumnya, dan pengembangan tanah Papua pada khususnya;

c. Memainkan perannya sebagai agen perubahan dalam menunjang pembangunan propinsi Papua Barat khususnya, dan pembangunan nasional secara umumnya;

d. Mengemban tata kehidupan kampus yang dapat menunjang perwujudan secara nyata kepribadian manusia yang manusiawi dan bermartabat. ${ }^{9}$

Perkembangan pendidikan dalam lima tahun terakhir mulai mengalami peningkatan. Menurut data pada tahun 2012, Sorong memiliki 45 sekolah Taman KanakKanak, 127 SD, 34 SLTP, 20 SLTA/MA, 6 SMK, dan sebuah perguruan tinggi. Sampai tahun 2011, jumlah tenaga pendidik sudah mencapai 1.307 guru. Jumlah itu tentunya masih jauh dari kebutuhan karena guru yang dibutuhkan berjumlah 1.958 orang. ${ }^{10}$ 
Corak kehidupan masyarakat dan Gereja Papua itu pula yang menjadi dasar bagi STPK St. Benediktus untuk mengembangkan program pendidikan yang saling menunjang antara ilmu-ilmu kemanusiaan, Kitab Suci, teologi, budaya dan pastoralkateketik.

Dalam seluruh proses pendidikannya, STPK St. Benediktus berupaya membantu mahasiswa menemukan arah yang tepat bagi pengembangan dirinya agar mampu merefleksikan Sabda Tuhan, berkatekese, dan melakukan pelayanan pastoral dalam konteks Papua masa kini.

STPK St. Benediktus dibuka karena adanya tuntutan yang semakin berat terhadap pembiayaan mahasiswa-mahasiswi calon guru agama katolik/katekis, sertifikasi guru Agama Katolik yang dituntut pemerintah, dan tuntutan kebutuhan lapangan yang semakin besar dengan adanya pemekaran propinsi maupun kabupaten. Oleh karena itu, sejalan denganprogram kepedulian Uskup Manokwari-Sorong, dalam peningkatan mutu pendidikan dasar bagi anak-anak pedalaman, dalam pembicaraan temu pastores dan dewan keuskupan direncanakan untuk membuka STPK bagi para calon guru agama katolik di wilayah Kepala Burung, Keuskupan Manokwari-Sorong.

STPK St. Benediktus merupakan sebuah perguruan tinggi swasta yang dikelola oleh Yayasan Paramitha Katolik Sorong, yang merupakan sebuah yayasan di bawah Keuskupan Manokwari-Sorong. Kehadiran STPK ini sejalan dengan amanat perjuangan untuk mencapai tujuan nasional seperti yang tercantum dalam UndangUndang Dasar 1945, yakni: terus mencerdaskan kehidupan bangsa serta mewujudkan tercapainya masyarakat yang adil dan makmur berdasarkan Pancasila.

STPK St. Benediktus menyelenggarakan program studinya sesuai dengan program PendidikanNasional (Ditjen Bimas Katolik) berdasarkan Sistem Kredit Semester (SKS) dengan jurusan dan program studi Ilmu Pastoral maupun Ilmu Kateketik. Walaupun nama dan program STPK disesuaikan dengan sistem pendidikan yang baru, perhatian STPK St. Benediktus untuk kebudayaan dan peningkatan mutu pendidikan dasar tidak berkurang. Yang ingin ditekankan ialah adanya hubungan erat antara ilmu ketuhanan dan medan hidup serta karya manusia di Tanah Papua ini. Maka, ilmu-ilmu kebudayaan dan ilmuilmu kemanusiaan lainnya tetap diberi tempat yang penting dalam program STPK, mengingat program peningkatan mutu pendidikan dasar yang secara pasti melibatkan ilmu pendidikan dan ilmu-ilmu umum lainnya.

Padabulan Januari 2008 diajukan permintaan untuk mendapatkan status "Ijin" pendirian kepada Direktur Jenderal Bimas Katolik. Ternyata Dirjen sangat merespon pendirian STPK ini; karena itu pada tanggal 14 Mei 2008 memberikan ijin pendirian dengan Nomer : Dj. IV / hk.00.5 /75 / 2008. Sejak tanggal 9 Januari 2015, STPK St. Benediktus telah berhasil terakreditasi oleh Badan Akreditasi Nasional Perguruan Tinggi (BAN PT) dengan nomor: 004/SK/BAN- PT/Akred/S/I/2015.

Masyarakat Papua, secara khusus Keuskupan Manokwari Sorong patutlah bersyukur atas pendirian Sekolah Tinggi Pastoral Kateketik ini. Sebab di sekolah inilah terdapat potensi yang sangat berarti demi kepedulian Keuskupan ManokwariSorong dalam pewartaan Kabar Sukacita Tuhan.

Sebagai sebuah institusi sekolah, STPK St. Benediktus Sorong mendasarkan seluruh proses pendidikannya pada visi dan misi sekolah. Adapun visi dan misi yang dimaksud antara lain:

\section{VISI}

Terbentuknya tenaga pendidik dan pengajar agama Katolik yang profesional, beriman teguh, Pancasilais, tanggap dan tangguh serta mandiri melalui kinerja lembaga yang sehat

\section{MISI}

1. Melaksanakan dan mengembangkan pendidikan dan pengajaran Agama Katolik yang otentikdan kontekstual. 
2. Melaksanakan pelatihan ketrampilan kateketik pastoral yang terprogram secara sistematis dan terpadu.

3. Melaksanakan penelitian untuk pengembangan karya pendidikandan pengajaran Agama Katolik.

4. Melaksanakan pengabdian masyarakat dengan semangat pelayanan.

5. Melaksanakan dan mengembangkan pendidikan yang berorientasi pada kemandirian.

6. Melaksanakan pembinaan civitas akademika yang berwawasan kebangsaan. ${ }^{11}$

Berdasarkan inspirasi visi dan misi tersebut, maka jelaslah bahwa semangat kristiani dalam hal ini spiritualitas Santo Benediktus yang terus menerus mewartakan Salib adalah Terang bagi hidup, mewarnai setiap gerak langkah yang ada di dalam lembaga ini.

Semangat ini tercermin dalam ciri khas STPK seperti yang dirumuskan dalam Statuta Bab III pasal 5, yakni :

1. Memenuhi tanggung jawab Gereja Katolik dan awam Katolik dalam pengelolaan Sekolah Tinggi Pastoral Kateketik;

2. Mengakui kebebasan akademik;

3. Menempatkan pendidikan agama dan etika sebagai bagian integral dari kurikulum Sekolah Tinggi Pastoral Kateketik;

4. Mewujudkan secara konsisten sikap kepedulian kepada kaum yang lemah; mereka yang belum/kurang berpendidikan;

5. Mengelola pendidikan dan administrasi secara transparan;

6. Menanamkan dan mengembangkan prinsip solidaritas dan subsidiaritas, serta sikap disiplin;

7. Memiliki kepedulian terhadap pengembangan pribadi setiap warga Keluarga Besar YayasanParamitha Katolik.

\section{MENGAPA MASUK KE STPK ST. BENEDIKTUS: SEBUAH PENDALAMAN MOTIVASI}

Permasalahan tentang pendidikan dan masih kurangnya ketersediaan guru agama, sangatlah menarik untuk kita lihat dan dalami bersama. Oleh karena itu, peneliti mengangkat permasalahan ini. Untuk semakin mempertajam pokok permasalahan, peneliti mengambil obyek dan lingkup penelitian di STPK St. Benediktus Sorong. Mengapa mengambil obyek dan penelitian di sekolah ini? Karena di sekolah inilah nantinya dihasilkan para guru Agama Katolik dan para katekis yang akan terjun di tengah-tengah umat. Peneliti akan mencoba menggali dan mendalami apa sebenarnya motivasi mereka mengambil keputusan untuk masuk di sekolah untuk para calon guru Agama Katolik dan katekis. Dari pendalaman ini, diharapkan nantinya akan dapat sedikit menjawab pokok permasalahan dalam penelitian ini. Dari pendalaman masalah ini pula, peneliti akan mencoba memberikan masukan untuk proses pendidikan bagi para calon guru agama Katolik.

Untuk dapat mengetahui alasan seseorang melakukan atau mengerjakan sesuatu, kita perlu terlebih dahulu mengetahui apa motivasi awal mereka melakukan atau mengerjakan hal itu. Motivasi atau motif menandakan "alasan (dari kata alas: dasar) yang mengarahkan" secara aktif untuk menginginkan sesuatu dan untuk bertindak guna mencapainya. Motivasi dapat bercorak emosional (misal: nafsu) maupun intelektual dan dapat tidak disadari oleh pelaku (misal: nilai-nilai yang positif maupun negatif). Seberapa kuat pengaruh motif afektif dibandingkan dengan pengetahuan atau pertimbangan intelektual sulit untuk ditentukan dalam tindakan konkret, antara lain karena motifmotif bukan intelektual dapat secara tidak sadar dirasionalisasi. Dalam teologi moral, motif dan motivasi mendapat perhatian. Motif atau motivasi yang baik saja tidak membenarkan sarana (misal: menipu) atau perbuatan yang jahat. Terhadap berbaga motif emosional atau rasionalisasi yang berganti-ganti, fundamental option, yakni: pengarahan diri yang fundamental dan etos 
seseorang agak menjamin ke mantapan serta penalaran moril yang sehat. Pengarahan dasar tersebut dibentuk perlahan antara lain atas dasar iman atau keyakinan.

\section{APAKAH MOTIVASI MASUK KE STPK ST. BENEDIKTUS?}

Semua manusia memiliki perjuangan atau kecenderungan yang dibawa sejak lahir untuk mengaktualisasikan diri. Kita didorong oleh kebutuhan-kebutuhan universal dan yang dibawa sejak lahir, yang tersusun dalam suatu tingkat, dari yang paling kuat sampai kepada yang paling lemah. Tingkat kebutuhan kita sebagai manusia dapat kita umpamakan sebagai tingkat kebutuhankebutuhan, seperti suatu tangga, kita harus meletakan suatu kaki pada anak tangga pertama sebelum berusaha mencapai anak tangga kedua, dan pada anak tangga kedua sebelum anak tangga ketiga dan seterusnya. Dengan cara yang sama pula, kebutuhan yang paling rendah dan paling kuat harus dipuaskan sebelum muncul kebutuhan tingkat kedua dan seterusnya naik tingkat sampai muncul kebutuhan kelima dan yang paling tinggi: aktualisasi. ${ }^{12}$

Prasyarat untuk mencapai aktualisasi diri ialah memuaskan empat kebutuhan yang berada dalam tingkat yang lebih rendah, yaitu: (1) kebutuhan-kebutuhan fisiologis, (2) kebutuhan-kebutuhan akan rasa aman, (3) kebutuhan-kebutuhan akan memiliki dan cinta, (4) kebutuhankebutuhan akan penghargaan. ${ }^{13}$ Macammacam kebutuhan tersebut akan mempengaruhi berbagai macam motif atau motivasi seseorang dalam melakukan sesuatu hal.

Berbagai motif dapat mengawali keputusan dan tindakan kita. Motivasi rohani misalnya dapat mendorong orang untuk maju mencapai cita-citanya. Dalam usaha ini, kita sering mengalami pertentangan dan kebingungan batin, sehingga perlu membedakan motivasi-motivasi yang tidak teratur, yang kerapkali tidak sesuai dengan nilai-nilai kita sebagai orang beriman. Maka, kita perlu menyelidiki batin kita, memurnikan motivasi dengan membedakan roh yang berbeda-beda yang mendorong dan menarik kita. Sebelum suatu keputusan penting (panggilan, pekerjaan, teman hidup, dll) diambil, sebaiknya diusahakan supaya motif-motif kita sadari dengan sungguh-sungguh.

Segi sentral dari kepribadian seseorang yang matang dan dewasa adalah intensiintensiyang sadar dan sengaja, yakni harapan-harapan, aspirasi-aspirasi, dan impianimpian. Tujuan-tujuan ini mendorong kepribadian yang matang dan member petunjuk yang paling baik untuk memahami tingkah laku seseorang. Seorang ahli psikologi bernama G. Allport, mengatakan: "Memiliki tujuan-tujuan jangka panjang yang dilihat sebagai pusat dari kehidupan pribadi seseorang, membedakan manusia dari binatang, orang dewasa dari anak-anak, dan dalam banyak hal kepribadian yang sehat dari kepribadian yang sakit." 14

Beberapa teori motivasi menegaskan bahwa manusia didorong pertama-tama untuk mereduksikan tegangan-tegangan, menjaga supaya tegangan-tegangan berada pada tingkat yang paling rendah, dan dengan demikianmenjaga suatu keadaan keseimbangan homeostatis internal atau "homeostatis. Dalam pandangan ini, individu-individu didorong oleh tegangan yang berlebihan sehingga mereka terusmenerus didorong untuk mereduksikannya. ${ }^{15}$

Yang menarik kemudian adalah bagaimana dan apa sebenarnya motivasi para mahasiswa-mahasiswi yang masuk ke STPK St. Benediktus. Dengan konteks sejarah, latarbelakang, dan visi misi Sekolah seperti yang dijelaskan di atas, apakah motivasi para mahasiswa dan mahasiswi masuk STPK sesuai dengan itu semua. Inilah yang menarik untuk kita lihat lebih lanjut.

Untuk mengetahui motivasi mahasiswamahasiswi masuk ke STPK St. Benediktus, kami telah menyampaikan sebuah pertanyaan mendasar kepada mereka, yaitu: "Apa motivasi anda untuk masuk ke STPK St. Benediktus Sorong?" Hasil jawaban dari pertanyaan tersebut adalah sebagai berikut: 
Tabel A. Hasil Rekap Jawaban Responden ${ }^{16}$

Pertanyaan Utama: Apa motivasi anda masuk ke STPK St. Benediktus Sorong

\begin{tabular}{|c|c|c|c|}
\hline NO & JAWABAN & JUMLAH & $\begin{array}{l}\text { KETERANGA } \\
\mathrm{N}\end{array}$ \\
\hline 1 & Cita-cita awal memang ingin menjadi guru Agama Katolik & 38 orang & \\
\hline 2 & $\begin{array}{l}\text { Mewartakan Kristus dan Kerajaan Allah (memperdalam } \\
\text { iman dan pengetahuan agama) }\end{array}$ & 25 orang & \\
\hline 3 & $\begin{array}{l}\text { Tidak tahu mau melanjutkan ke mana setelah lulus: kuliah } \\
\text { atau kerja? }\end{array}$ & 4 orang & \\
\hline 4 & Dorongan dari keluarga & 14 orang & \\
\hline 5 & $\begin{array}{l}\text { Menjadi orang yang berguna untuk bangsa, Negara, dan } \\
\text { sesama }\end{array}$ & 6 orang & \\
\hline \multirow[t]{2}{*}{6} & Peluang kerja terbuka sebagai Guru Agama & 2 orang & \\
\hline & JUMLAH & 89 orang & \\
\hline
\end{tabular}

\section{APAKAH PANGGILAN HIDUP MENJADI GURU AGAMA KATOLIK: MASIH RELEVAN?}

Pada bagian ini,kita akan mencoba untuk menghubungkan motivasi atau alasan-alasan mahasiswa/i STPK St. Benediktus Sorong dengan pokok permasalahan dalam penelitian ini: Apakah panggilan hidup menjadi guru Agama Katolik masih relevan?

Seperti yang terlihat dalam Tabel A,dari 150 orang, ada 38 orang mahasiswa yang menjawab bahwa cita-cita awal memang ingin menjadi guru Agama Katolik, 25 orang ingin memperdalam iman dan pengetahuan akan agama, 4 orang menjawab karena tidak tahu akan melanjutkan ke mana, 14 orang karena dorongan dari keluarga, 6 orang karena ingin menjadi orang yang berguna untuk bangsa, negara dan sesama, serta 2 orang dengan alasan peluang kerja yang masih terbuka sebagai guru agama. Data-data ini mau bicara apa sekarang? Inilah yang akan coba kita lihat dan dalami bersama.

Dari data tersebut, patutlah untuk bersyukur bahwa ternyata masih ada orang yang bercita-cita ingin menjadi seorang guru Agama Katolik (38 orang: lih. Tabel A.1). Dari berbagai tawaran dan pilihan hidup yang bervariasi serta menarik di zaman modern sekarang ini, setidaknya masih ada 38 orang yang memiliki cita-cita menjadi seorang guru agama Katolik, adalah sesuatu yang luar biasa, terlebih lagi bahwa cita-cita tersebut memang telah ada dan tertanam sejak kecil. Dari hasil jawaban yang mahasiswa berikan, ada berbagai macam alasan mengapa mereka tertarik untuk bercita-cita menjadi seorang guru agama Katolik, diantaranya adalah:

- Melihat sosok guru agama yang berwibawa dan dapat memberikan pengetahuan iman serta agama kepada orang lain.

- Keprihatinan akan kurangnya tenaga guru agama di tempat tinggalnya.

Apapun yang menjadi alasan orang bercita-cita menjadi seorang guru agama, keinginan tersebut sungguh-sungguh suatu keinginan yang sangatlah baik. Hal inilah yang dimaksud sebagai sebuah lingkaran motivasi (lih. Tabel B: Diagram Lingkaran Motivasi). Motivasi itu muncul pertamatama karena faktor ketidakseimbangan yang terjadi, adanya kekurangan tenaga guru Agama Katolik. Kebutuhan ini akhirnya dapat membuat seseorang akhirnya menjadi tertarik untuk menjadi seorang guru Agama Katolik. Selain itu, motivasi menjadi 
seorang guru Agama Katolik muncul karena tingkah laku, karena melihat sosok seorang guru agama yang berwibawa, yang dapat memberikan pengetahuan iman dan agama kepada orang lain. Tingkah laku yang positif dari seorang guru agama inilah yang akhirnya juga dapat menarik seseorang untuk bercita-cita sebagai seorang guru agama. Seperti dalam penjelesan tentang pendalaman motivasi, dalam suatu motif, umumnya terdapat dua unsur pokok, yaitu: unsur dorongan atau kebutuhan dan unsur tujuan. Dua unsur inilah yang nampaknya mewarnai motivasi para mahasiswamahasiswi untuk masuk ke STPK St. Benediktus.

Data yang menarik selanjutnya adalah ada 25 orang (Lih. Tabel A.2)yang memberikan alasan masuk ke STPK St. Benediktus Sorong karena ingin mewartakan Kristus dan Kerajaan Allah (memperdalam iman dan pengetahuan agama). Motivasi inilah yang disebut sebagai motivasi atau motif rohani. Orang mempunyai ketertarikan untuk dapat berhubungan dengan Allah. Alasan-alasan seperti inilah yang seringkali menjadi alasan orang untuk membaktikan diri kepada Allah dengan menjadi seorang imam, bruder, ataupun suster.Alasan inilah yang dapat pula menjadi alasan orang untuk menjadi seorang guru agama ataupun seorang tenaga pastoral (katekis). Oleh karena itu, sebenarnya dapat pula dikatakan bahwa 25 orang ini sebenarnya juga mempunyai ketertarikan untuk mengabdikan diri menjadi tenaga pendidik seorang guru Agama Katolik. Artinya, mereka sudah memiliki alasan dan motivasi yang cukup untuk menjadi seorang guru agama Katolik. Motivasi yang semacam ini setidaknya juga perlu disyukuri karena ternyata masih ada remaja yang memiliki motivasi rohani dalam pilihan dan jalan hidupnya. Maka, kalau mau sedikit dipaksakan, setidaknya ada 58 orang (Liht. Tabel A1 dan A2) mahasiswa-mahasiswi yang memiliki motivasi sejak awal untuk menjadi seorang guru Agama Katolik. Jumlah yang sekiranya cukup.

Data lain yang perlu dicermati adalah ada 14 orang yang masuk STPK St. Benediktus dengan alasan karena dorongan dari keluarga (Lih. Tabel A4).Jika dilihat dari motivasinya karena dorongan dari keluarga, maka sebenarnya ada keterpaksaan. Jika sesuatu dilakukan dengan keterpaksaan, maka juga akan mempengaruhi proses selanjutnya. Motivasi semacam ini tidaklah salah, tetapi perlu dicermati dan diperhatikan sungguh-sungguh agar dalam proses selanjutnya, mahasiswamahasiswi tidak kehilangan orientasi, tidak semaunya sendiri atau malah mungkin menjadi tertekan dan berat untuk menjalani proses perkuliahan. Data lain yang juga perlu diperhatikan dan diwaspadai adalah 4 orang yang mengatakan bahwa alasan atau motivasi mereka masuk ke STPK St. Benediktus karena mereka tidak tahu akan melanjutkan ke mana lagi. Dengan kata lain, STPK St. Benediktus menjadi alternatif terakhir karena tidak tahu akan melanjutkan ke mana lagi. Mahasiswa dengan motivasi semacam ini, dapat pula kehilangan orientasi dalam menjalani proses perkuliahannya, karena memang sejak awal mahasiswa tidak tahu alasannya menjalani perkuliahan di STPK St. Benediktus.

Data lain yang juga menarik adalah ada 6 orang (Lih. Tabel A5) yang mengatakan bahwa mereka memilih masuk ke STPK St. Benediktus agar dapat menjadi orang yang berguna. Motivasi semacam ini tentu dilandasi dengan sebuah kesadaran bahwa ada kemauan, ada dorongan, ada gerak untuk menjadi lebih baik, menjadi lebih berguna. Orang dengan motivasi semacam ini jika benar-benar diarahkan dapat benarbenar memberikan semangat dan motivasi yang sangat kuat bagi yang bersangkutan untuk menjalani proses perkuliahan.

\section{MENUMBUHKAN PANGGILAN HIDUP}

Apapun motivasi, alasan ataupun motif seseorang untuk memutuskan serta menjalani suatu pilihan, tetap harus disadari bahwa semuanya itu adalah suatu proses. Artinya, apapun motivasi yang dimiliki oleh seseorang dalam menjalani suatu keputusan ataupun suatu pilihan hidup, tidak dapat dijadikan patokan atau ukuran bahwa motivasi atau pilihan hidupnya itu adalah salah.Bisa jadi dalam 
proses selanjutnya, motivasi yang sebenarnya tidak sesuai dengan keputusan ataupun pilihan hidupnya, ternyata mengalami pemurnian motivasi yang akhirnya memberikan pengaruh yang sangat positif dalam perkembangan pilihan atau keputusan hidupnya.

Begitu halnya dengan motivasi-motivasi yang dimiliki oleh mahasiswa-mahasiswi STPK St. Benediktus Sorong (Lih. Kembali Tabel A), ada setidaknya 6 macam motivasi yang mendasari mereka memilih dan memutuskan untuk masuk ke perguruan tinggi ini, yaitu:

1. Motivasi awal memang bercita-cita untuk menjadi seorang Guru Agama Katolik.

2. Mewartakan Kristus dan Kerajaan Allah (memperdalam iman dan pengetahuan akan agama).

3. Tidak tahu mau melanjutkan ke mana setelah lulus: kuliah atau kerja.

4. Dorongan dari keluarga.

5. Menjadi orang yang berguna untuk bangsa, negara dan sesama.

6. Peluang kerja masih terbuka jika menjadi seorang guru agama (faktor ekonomi)

Motivasi-motivasi seperti itu sebenarnya adalah suatu proses bagi seorang mahasiswa dalam perjalanan dan pilihan hidupnya. Bagaimanapun mahasiswa tidak dapat disalahkan ketika memiliki motivasi semacam apapun juga, misalnya: dengan motivasi tidak tahu akan melanjutkan ke mana lagi atau dengan motivasi masuk STPK karena dorongan orangtua. Dalam proses pendidikan selanjutnya, motivasi mahasiswa-mahasiswi dengan sendirinya akan mengalami pemurnian. Bisa jadi mereka akan mengalami perubahan motivasi ketika sudah menjalani sendiri seluruh proses pendidikan di STPK St. Benediktus. Artinya,bisa jadi dalam perjalanan selanjutnya, mereka akhirnya memiliki motivasi yang sangat kuat dalam menjalani pilihan dan keputusan mereka untuk menjadi guru agama Katolik (bdk. Kisah pertobatan Santo Paulus). Atau malah bisa juga sebaliknya bahwa mereka yang dulu masuk dengan motivasi yang sangat baik karena memang ingin menjadi guru Agama Katolik, dalam proses pendidikan selanjutnya malah kehilangan motivasi dan semangatnya.

Dengan visi dan misi seperti dijelaskan pada bagian sebelumnya, STPK St. Benediktus Sorong ingin menjadi sebuah sekolah unggulan di Tanah Papua dengan didasari moral dan iman yang kokoh, dalam mengembangkan, melayani serta memanfaatkan secara manusiawi ilmu pengetahuan, secara khusus bidang pastoral dan katekese serta mampu menerapkan Ajaran Iman Gereja dalam situasi riil masyarakat. STPK St. Benediktus Sorong sungguhsungguh mendidik para mahasiswamahasiswi agar terampil dalam bidang pastoral, tanggap dan peka terhadap situasi riil masyarakat, bertanggungjawab serta siap sebagai tenaga-tenaga pendidik dan pengajar Agama Katolik.

Visi dan misi tersebut hanya dapat diwujudkan dengan menyelenggarakan pendidikan yang bermutu dan profesional sehingga menjadi rujukan, serta melalui arah pendidikan yang kuat dalam penguasaan bidang katekese dan pastoral. selain pendidikan, penelitian dan pelayanan pastoral yang dilakukan pun harus menunjang serta bermanfaat bagi kepentingan masyarakat. oleh karena itu, STPK St. Benediktus sorong bertujuan menghasilkan lulusan yang kompeten, dan handal di bidang pelayanan katekese dan pastoral, sehingga dapat memenuhi kebutuhan dan kerinduan umat akan bidang pelayanan pastoral. Hal inilah yang menjadi tujuan yang ingin dicapai STPK St. Benediktus sorong yang direalisasikan dalam bentuk peningkatan pelayanan dan penelitian antara dosen dan mahasiswa, dimana mahasiswa diikutsertakan dalam kegiatan dosen pada program pelayanan, penelitian dan pengabdian masyarakat, melalui praktek mengajar di sekolah-sekolah, pelayanan pastoral di lingkungan-lingkungan, sehingga diharapkan kegiatan tersebut dapat membentuk mahasiwa sebaga tenaga-tenaga pendidik dan pastoralyang siap di pakai di tengah-tengah umat atau masyarakat. Diharapkan kemudian dilanjutkan dengan perekrutan mereka sebagai tenaga pendidik dan 
pengajar, serta tenaga pastoral di sekolah, instansi, atau lingkungan setempat. penyelenggarakan pendidikan yang efisien dengan tatakelola yang baik membutuhkan dukungan sarana dan prasarana, lahan berpastoral dan sistem informasi yang baik dan mudah dipergunakan. oleh karena itu, STPK St. Benediktus sorong bersama-sama dengan instansi-instansi yang terkait, sekolah-sekolah, parokiparoki, membentuk kerja-sama dan pusat penjaminan mutu untuk menjamin mutu pelayanan terhadap mahasiswa.

Dengan visi, misi, program kegiatan, perkuliahan yang diadakan di STPK St. Benediktus, sangat diharapkan akhirnya memang dapat menciptakan para katekis dan guru-guru agama katolik yang handal, yang militan memperjuangkan pewartaan sabda allah. oleh karena itu, motivasi apapun yang dimiliki oleh mahasiswa untuk masuk ke STPK St. Benediktus, perlu disadari bahwa itu adalah sebuah proses yang terus ditindaklanjuti, dijaga, dipelihara, dan dimurnikan selalu. sebagai orang beriman, kita yakin dan percaya bahwa roh kudus akan selalu berkarya dalam setiap peristiwa hidup manusia, sekecil apapun itu, segelap apapun itu, dan sesulit apapun itu.

\section{PERAN PENASEHAT AKADEMIK ATAU WALI STUDI DALAM PROSES PENDIDIKAN}

STPK St. Benediktus sebagai lembaga penyelenggara pendidikan formal perlu selalu merancang atau mendesain pola dan sistem pendidikan dan pembelajaran yang berorientasi pada nilai-nilai sosialbudaya, seperti metode sinergi-edukatif antara semua elemen pendidikan (dosen, mahasiswa, orang tua, yayasan, pemerintah, organisasi-organisasi eksternal lainnya) sehingga tercipta suasana pendidikan dan pembelajaran yang komunikatif, interaktif dan sosio kultural $^{17}$ dengan melihat hal itu, maka dalam sistem pendidikan di STPK St. Benediktus diterapkanlah sistem pendi-dikan dengan pola pendampingan dan pembimbingan, mengingat bahwa maha-siswa dalam keseluruhan proses pendidikannya memang haruslah didampingi dan dibimbing. berdasarkan buku pedoman akademik STPK St. Benediktus sorong, ditunjuklah seorang penasehat akademik (pa) atau wali studi, yang mempunyai tugas antara lain:

1. Tugas penasehat akademik (PA) ialah mendampingi mahasiswa/i yang diperca-yakan kepadanya oleh sekolah untuk menyusun program studi, baik pada waktu perencanaan pendaftaran tiap semester maupun selama studi pada jenjang Strata Satu (S-1). Ia mendampingi mahasiswa/i dengan tujuan menjaga kemajuan studinya supaya bisa lulus dalam jangka waktu yang paling cepat. Sesudah tahun percobaan (semester 1+2), PA mengikuti perkembangan mahasiswa/i asuhannya sepanjang enam semester [semester 3 s/d 8].

2. PA menjadi penasehat untuk membantu mahasiswa/i memahami dan menggunakan sistem pendidikan SKS dan kurikulum serta program studi di STPK. Ia juga menyertai dan membantunya menyesuaikan diri dengan proses belajar mengajar di perguruan tinggi. Ia mendampingi mahasiswa/i sepanjang proses studi demi tercapainya identitas dan ketrampilan kesarjanaan di dalam dan melalui proses studinya.

3. PA ditugaskan oleh pimpinan sekolah dan secara khusus bekerja sama dengan Pembantu Ketua I dalam bidang akademik. PA berwenang untuk mengesahkan rencana studi semesteran yang disusun oleh mahasiswa/i dan menyatakan matakuliah tertentu dari jenjang studi tidak wajib. PA merupakan pelaksana praktis [gugus depan] program akademik untuk tiap-tiap mahasiswa/i. Ia berwenang untuk mewakili sudut manusiawi yang luwes dari program untuk mahasiswa/i supaya terhindar kesan "birokrasi dan legalisme" yang merajalela dalam sistem persekolahan. PA memantau perkembangan studi tiap-tiap mahasiswa/i yang dipercayakan kepadanya dari semester ke semester dengan mengindahkan IPS, IPK, jumlah SKS yang sudah diperoleh serta utang yang masih perlu dilunasi. 
PA tidak mencampuri soal-soal administratif [tugas BAAK] melainkan ia membantu agar mahasiswa/i mencapai sasaran jenjang studi pada akhir semester.Pada akhir jenjang S-1, PA lebih aktif turut membina mahasiswa/i merampungkan semua tugas serta utang dan menyelesaikan skripsi. Lain dari pada dosen, yang bertugas membina pengembangan mahasiswa/i di dalam menguasai bahan dan isi suatu matakuliah [substantif], maka PA bertugas menjaga supaya rangkaian matakuliah yang diikuti oleh peserta asuhannya memenuhi semua tuntutan program studi pada tiap semester [secara formal]. PA juga memantau kendornya semangat mahasiswa/i, secara khusus pada awal proses belajar [soal peralihan dari SLTA, soal memilih jurusan], pada pertengahan [konflik pemikiran dan putus asa, kesepian dalam riwayat seorang pelajar dan tekanan berat karena studi melebihi kesanggupan], dan pada akhir jenjang [soal rasa tidak bisa selesai, belum cukup mahir mengarang, konflik dengan dosen, dan sebagainya].PA bersendian dengan Pembantu Ketua I dan berurusan dengan senat dosen dalam memantau rencana studi semesteran dan seluruh jenjang strata satu (S-1) supaya masukan dari sudut pandang mahasiswa/i diwakili dalam pengambilan keputusan-keputusan dan kebijakan programatis. Secara istimewa perhatian diberikan kepada mahasiswa/i yang lemah karena ia berada dalam bahaya tidak meneruskan studi di STPK. Terutama PA memantau soal ketidaksanggupan mahasiswa/i belajar secara tepat.Matakuliah dasar yang merupakan "jodoh" para penasehat akademik ialah matakuliah metode belajar. Sesudah semester pertama, PA akan memperhatikan masalah apakah mahasiswa/i sedang maju secara metodologis dan berdaya guna dalam program studinya sepanjang jenjang S-1, baik dalam jam studi terstruktur maupun [dan lebih-lebih] dalam studi mandiri.PA juga memberi dorongan dan semangat khusus kepada mahasiswa/i luar biasa, yang IPK-nya tinggi, agar mereka ditantang secara khusus untuk tidak mengikuti pola yang biasa. PA mendorong mahasiswa/i yang berbakat demikian untuk belajar tekun dan lebih rajin demi kelanjutan studi sesudah S-1 [misalnya soal menekuni bahasa Inggris, matematika, mengarang, membaca secara mandiri].

4. Sebagai wali studi [istilah lain untuk PA reguler] PA lebih memantau proses belajar yang sedang terjadi di dalam peserta asuhannya.Tujuan pendidikan yang mau dicapai melalui program akademik ialah pengertian dan pemahaman serta pengintegrasian secara kognitif dan konatif melalui perangkat pengertian dan kemahiran yang disajikan oleh program studi STPK. Maka wali studi menjadi wali sehubungan dengan tujuan kurikuler dan sahabat proses kemajuan ilmiah mahasiswa/i.Wali studi dipilih dari antara dosen-dosen justru untuk pengintegrasian bidang ilmunya yang sedang dan bakal terjadi dalam diri mahasiswa/i sesuai dengan proses seperti yang sudah dan sedang terjadi di dalam diri dosen sendiri sebagai penggemar studi pastoral-kateketik yang sama.

Proses belajar di perguruan tinggi bukan berupa penambahan informasi saja, belajar di perguruan tinggi diharapkan menghasilkan proses perubahan mental karena membebaskan mahasiswa/i dari prasangka, praandaian dan prafaham yang perlu dikritik dan dinilai oleh pertimbangan rasional dan logis. Walaupun dosen matakuliah berupa "gugus depan" dalam proses belajar dan pengintegrasian ini, namun wali studi mendampingi mahasiswa/i lebih lama [delapan semester] dan lebih luas [semua matakuliah] dari pada seorang dosen.

Sering terjadi bahwa pemikiran seorang mahasiswa/i tidak berkembang sesuai dengan irama semester, malah karena "learning lag", mahasiswa/i baru menjadi insyaf akan dampak pemikiran kritis dua semester kemudian. Wali studi bertugas mendampingi proses-proses pemekaran, kesinambungan dan penginsyafan ini sepanjang jenjang program. Secara istimewa wali studi bertugas memikirkan secara kritis dan secara 
berkala apakah peserta didik yang diasuhnya sedang mencapai tujuan kurikuler atau justru dihambat olehnya. Pengintegrasian konatif dalam diri mahasiswa/i dipantau dari sudut mutu pengalaman dan kwalitas praktek serta latihan ketrampilan yang dijalankan sesuai dengan tujuan kurikuler (40\%) dengan menimbang kenyataan yang terjadi di dalam semester yang sedang berjalan. Perwalian dari wali studi bercorak 'sahabat' dengan tujuan konatif menuju sasaran akhir dan kemahiran praktis yang diidamkan oleh program studi STPK. Wali studi memantau sejauh mana proses belajar mengajar mencapai pengintegrasian di dalam diri mahasiswa/i pada tiap tahun dan maju menuju sasaran akhir program. Tentu disintegrasi (krisis) yang terjadi pada semester dan tahun tertentu diharapkan menjadi tanda perkembangan.

5. Istilah wali angkatan merupakan nama lain untuk Penasehat Akademik atau Wali Studi di STPK, karena pembagian jumlah mahasiswa/i di antara PA lebih mudah kalau menurut angkatanangkatan. Bisa jadi kelak bahwa lebih tepat membagi penasehat akademik bagi kelompok-kelompok menurut pola angkatan dan jurusan sesudah semester ke-4. Adanya Wali Angkatan bukan bararti bahwa semua pembinaan terjadi menurut pola angkatan atau bahwa pola angkatan masih merupakan dasar unggul untuk pembinaan kepribadian.Angkatan diartikan sebagai kelompok akademis yang anggota-anggotanya bertautan satu sama lain karena studi dan matakuliah. Angkatan dipilih sebagai kesatuan yang relatif sama secara fungsional/akademis dan berjumlah relatif kecil demi pembinaan akademik.Ciri khas penasehat akademik ialah bidang akademik, yang diunggulkan sekolah justru dengan cara penjabaran waktu dan upaya yang dituntut dari mahasiswa/i. Secara kasar dapat disimpulkan: PA berkecimpung di bidang akademik dan bukan di bidang bimbingan kepribadian. ${ }^{18}$

\section{PENUTUP}

Dengan melihat situasi dan kondisi di tanah Papua yang masih membutuhkan begitu banyak sentuhan tangan demi kemajuan seluruh masyarakat, kehadiran STPK St. Benediktus pantaslah dihargai dan didukung. Dari sekolah inilah nanti akan muncul para katekis dan guru-guru agama yang akan terjun langsung di tengahtengah masyarakat, berjuang bersama mereka dalam suka dan duka, sambil menebarkan cinta kasih Kristus.

Berapapun prosentase mahasiswa/i yang memutuskan untuk masuk ke STPK St. Benediktus Sorong, juga menjadi berkat tersendiri secara khusus bagi Gereja Keuskupan Manokwari-Sorong. Dari begitu banyak tawaran dan pilihan akan masa depan yang lebih menjanjikan, mahasiswa/i STPK St. Benediktus Sorong telah ambil bagian dalam tugas pelayanan Kristus dengan memberikan dirinya untuk digembleng, dididik, dan dibentuk agar nantinya siap untuk kembali ke masyarakat. Segala macam bentuk pendidikan dan pengajaran yang mereka dapatkan selama perkuliahan di STPK St. Benediktus Sorong akan benarbenar menjadi bekal yang sangat berharga dan ampuh bagi mereka untuk menjadi "sinar dan terang dunia", seperti semboyan STPK St. Benediktus Sorong: "Crux Mihi Lux."

\section{Ady Bintoro}

Dosen di Sekolah Tinggi Pastoral Kateketik (STPK) Santo Benediktus Sorong, serta Pembantu Ketua I di STPK St. Benediktus Sorong.Email: adybintoro13@gmail.com

\section{CATATAN AKHIR}

1 Palmer J.A, 50 Pemikir Pendidikan: dari Jean Piaget sampai Masa Sekarang, (Yogyakarta: Jendela, 200), 320.

2 Ensiklopedi Pendidikan, (Jakarta: Gunung Agung), 254.

3 Marsel M. Lintong, Gagasan-Gagasan Pendidikan Kontemporer Pemberdayaan Mutu Pendidikan di Indonesia, (Jakarta: Cahaya Pineleng, 2010), 157.

4 Suparlan Suhartono, PhD, Wawasan Pendidikan, Sebuah Pengantar Pendidikan, (Yogyakarta: ArRuzz Media, 2008), 87. 
5 Sebagian besar informasi dan data-data diambil dari "Buku Kenangan 60 Tahun Paroki Kristus Raja Katedral Keuskupan Manokwari Sorong” 24 November 2007

6 Sebagian besar data-data yang diambil bersumber dari Buku Pedoman Sekolah Tinggi Pastoral Kateketik Santo Benediktus Sorong

7 Sekolah Tinggi Pastoral Kateketik (STPK) Santo Benediktus Sorong beralamatkan di Jln. RA. Kartini No 02 Kampung Baru, Sorong, Papua Barat.

8 Papua merupakan pulau terbesar kedua di dunia. Sekitar tahun 200 Masehi, ahli Geografi bernama Ptolamy menyebut Papua dengan nama Labadios. Akhir tahun 500 Masehi, Pengarang Tiongkok bernama Ghau Yu Kua memberi nama Tungki, dan pada akhir tahun 600 Masehi, Kerajaan Sriwijaya menyebut Papua dengan nama Janggi. Tidak ketinggalan pula Tidore juga memberi nama untuk pulau ini dan penduduknya dengan nama Papa-ua yang kemudian berubah nama menjadi Papua.

9 Diambil dari Rencana Induk Pengembangan (RIP) STPK St. Benediktus Sorong

10 Drs. Stepanus Malak, M. Si dan Wa Ode Likewati, SE, MM, Emas Hitam dari Sorong Menuju Peradaban Baru, 126.

11 Diambil Statuta Sekolah Tinggi Pastoral Kateketik Santo Benediktus Sorong

12 Maslow, A.H, "Self Actualization and Beyond", In J.F.T. Bugental, ed, Challenges of Humanistic Psychology, New York: Graw-Hill,(1967): 279.

13 Duane Schultz, Psikologi Pertumbuhan ModelModel Kepribadian Sehat, (Yogyakarta: Kanisius, 2011), 90

14 G. Allport, Becoming: Basic Consideration for a Psychologi of Personality, (USA: New Haven, Yale University Press, 1955),51.

15 Duane Schultz, Psikologi Pertumbuhan ModelModel Kepribadian Sehat, 21.

16 Responden berjumlah 150 orang (mahasiswamahasiswi STPK St. Benediktus Sorong untuk seluruh semester). Angket pertanyaan dibagikan kepada mereka pada tanggal 13 Agustus 2012. Dari 150 angket, yang kembali berjumlah 89.

17 Dr. Wina Sanjaya, M.Pd, Perencanaan dan Desain Sistem Pembelajaran, (Jakarta: Kencana Prenada Media, 2008), 19.

18 Diambil dari Buku Pedoman Sekolah Tinggi Pastoral Kateketik Santo Benediktus Sorong yang disusun pada tahun 2008 dan direvisi ulang Agustus 2015.
18 Dr. Wina Sanjaya, M.Pd, Perencanaan dan Desain Sistem Pembelajaran, (Jakarta: Kencana Prenada Media, 2008), 19.

18 Diambil dari Buku Pedoman Sekolah Tinggi Pastoral Kateketik Santo Benediktus Sorong yang disusun pada tahun 2008 dan direvisi ulang Agustus 2015

\section{DAFTAR RUJUKAN}

Allport, G, Becoming: Basic Consideration for a Psychologi of Personality, USA: New Haven, Yale University Press, 1955.

Jeane. A, Palmer, 50 Pemikir Pendidikan: dari Jean Piaget sampai Masa Sekarang, Yogyakarta: Jendela, 2003,

Lintong M., Marsel, Gagasan-Gagasan Pendidikan Kontemporer Pemberdayaan Mutu Pendidikan di Indonesia, Jakarta: Cahaya Pineleng, 2010 .

Maslow H, Abraham, "Self Actualization and Beyond", In J.F.T. Bugental, ed, Challenges of Humanistic Psychology, Mc. (New York: Graw-Hill),1967.

Sanjaya, Wina, Perencanaan dan Desain Sistem Pembelajaran, Jakarta: Kencana Prenada Media, 2008.

Schultz, Duane, Psikologi Pertumbuhan Model-Model Kepribadian Sehat, Yogyakarta: Kanisius, 2011.

$\begin{array}{ccr}\text { Suhartono, } & \text { Suparlan, } & \text { Wawasan } \\ \text { Pendidikan, } & \text { Sebuah } & \text { Pengantar } \\ \text { Pendidikan, } & \text { Yogyakarta: } & \text { Ar-Ruzz } \\ \text { Media, 2008. } & & \end{array}$


